\title{
Disability and workplace harassment and discrimination among Canadian federal public service employees
}

\author{
Andrea Marie Jones ${ }^{1} \cdot$ Rodrigo Finkelstein ${ }^{2} \cdot$ Mieke Koehoorn $^{1}$ \\ Received: 17 August 2017 / Accepted: 18 November 2017 / Published online: 20 February 2018 \\ (C) The Canadian Public Health Association 2018
}

\begin{abstract}
Objectives Policy and legislation that prohibits workplace harassment and discrimination, including that which is disability related, has been in place in Canada for many years. The study objective was to examine associations between disability and workplace harassment and discrimination in the current Canadian context, as well as the intersection of disability with age, gender, and ethnicity.

Methods Cross-sectional data from the 2014 Canadian Public Service Employee Survey was analyzed $(n=175,742)$ using logistic regression to investigate the relationship between self-reported disability and workplace harassment and discrimination in the last 2 years. Age, gender, and ethnicity were included as potential confounders and effect modifiers. Additive and multiplicative effect modifications were examined using linear binomial and logistic regression, respectively.

Results Overall, 18 and $8 \%$ of the sample of Canadian public service employees reported workplace harassment and discrimination, respectively. The prevalence was higher for workers with disability (37 and 26\%). Disability was significantly associated with an increased odds of harassment (odds ratio $(\mathrm{OR})=2.80 ; 95 \%$ confidence interval $(\mathrm{CI}), 2.68-2.92$ ) and discrimination $(\mathrm{OR}=4.97 ; 95 \% \mathrm{CI}, 4.72-5.23)$ in models adjusted for confounders. Significant positive additive effect modification was observed for (1) age in the harassment and discrimination models and (2) ethnicity in the discrimination model.

Conclusion Findings from a 2014 census of the Canadian federal public service suggest that additional efforts are needed to address workplace harassment and discrimination beyond those already in place. Consideration should be given to workers with disability, as well as the intersectional impacts for older workers, visible minorities, and Aboriginal peoples.
\end{abstract}

\section{Résumé}

Objectifs Des politiques et des lois interdisant le harcèlement et la discrimination en milieu de travail, notamment envers les personnes handicapées, existent depuis de nombreuses années au Canada. Nous avons voulu examiner les associations entre le handicap et le harcèlement et la discrimination au travail dans le contexte canadien actuel, ainsi que les croisements entre le handicap et l'âge, le sexe et l'ethnicité.

Méthode Nous avons analysé par régression logistique les données transversales de l'édition 2014 du Sondage auprès des fonctionnaires fédéraux du Canada $(n=175,742)$ pour examiner la relation entre le handicap autodéclaré et le harcèlement et la discrimination au travail au cours des deux années antérieures. L'âge, le sexe et l'ethnicité ont été inclus à titre de possibles facteurs confusionnels ou modificateurs de l'effet. La modification de l'effet a été examinée par régression linéaire binomiale (interaction additive) et par régression logistique (interaction multiplicative).

Résultats Dans l'ensemble, $18 \%$ et $8 \%$ de l'échantillon d'employés de la fonction publique canadienne ont fait état de harcèlement et de discrimination au travail, respectivement. La prévalence était plus élevée chez les employés handicapés (37\% et 26\%). Le

Andrea Marie Jones

andrea.jones@alumni.ubc.ca

1 School of Population and Public Health, University of British Columbia, 2206 E Mall, Vancouver, BC V6T 1Z9, Canada

2 School of Communication, Simon Fraser University, Burnaby, BC, Canada handicap présentait une corrélation significative avec une probabilité accrue de harcèlement (rapport de cotes $[\mathrm{RC}]=$ 2,80, intervalle de confiance [IC] de 95\%: 2,68-2,92) et de discrimination ( $\mathrm{RC}=4,97, \mathrm{IC}$ de $95 \%$ : 4,72-5,23) dans les modèles ajustés selon les facteurs confusionnels. Dans le modèle additif, une interaction positive significative a été observée 1) pour l'âge dans les modèles de harcèlement et de discrimination et 2 ) pour l'ethnicité dans le modèle de discrimination. 
Conclusion Les constatations d'un recensement mené en 2014 dans la fonction publique fédérale canadienne indiquent qu'il faut faire des efforts en plus de ceux qui sont déjà déployés pour contrer le harcèlement et la discrimination en milieu de travail. Il faudrait tenir compte des employés handicapés, ainsi que des incidences croisées sur les travailleurs âgés, les minorités visibles et les Autochtones.

Keywords Disabled persons $\cdot$ Workplace $\cdot$ Social discrimination $\cdot$ Ethnic groups $\cdot$ Gender $\cdot$ Age groups

Mots-clés Personnes handicapées $\cdot$ Lieux de travail $\cdot$ Discrimination sociale $\cdot$ Groupes ethniques $\cdot$ Genre $\cdot$ Tranches d'âge

\section{Introduction}

In Canada and many other industrialized countries, legislation prohibits workplace harassment and discrimination, including that associated with disability (Government of Canada 1985; U.S. Equal Employment Opportunity Commission 1990; Australian Government 2009; The Council of the European Union 2009). Harassment is improper conduct by an individual that is directed at, and offensive to, another individual; while discrimination is different or unfair treatment due to a personal characteristic or distinction that imposes disadvantage or limits access (see Appendix 1 for further explanation of these terms). Historically, people with disability have faced disproportionately high levels of harassment and discrimination in the workplace and other arenas of social life. In recent decades, evidence from the USA and the UK indicates that despite protective legislation, workplace harassment and discrimination remain elevated among workers with disability compared with workers with no disability (Fevre et al. 2013; Snyder et al. 2010). This has substantial implications for disabled workers' health and labour market outcomes, as discrimination and harassment are associated with poor physical and mental health as well as sickness absence, reduced productivity, and premature exit from the workforce (Okechukwu et al. 2014; Khubchandani and Price 2015; Pascoe and Smart Richman 2009).

In addition to disability, other known social determinants of workplace harassment and discrimination include younger or older age, being a woman, non-Caucasian ethnicity, and non-heterosexuality (Okechukwu et al. 2014). Focusing on workers with disability, American studies have found that the risk of workplace discrimination varies between disability subgroups defined by disability type, age, gender, and ethnicity (Rospenda et al. 2009; Ineson et al. 2013; Gee et al. 2007). This indicates that workers with disability are not a homogenous social group, and that intersections between disability and other social determinants of workplace harassment and discrimination need to be examined.

The first objective of this study was to examine associations between disability and workplace harassment and discrimination in the current Canadian labor market and legislative environment. While there has been examination of similar relationships in other countries, recent Canadian estimates are lacking. The second objective was to examine if age, gender, and ethnicity modify these relationships. Prior research comparing the risk of workplace discrimination across subgroups of American workers with disability examined the main effects of ethnicity, age, and gender, but not the modifying roles of these variables (Balser 2002; Shaw et al. 2012). To address these objectives, data were analyzed from a cross-sectional census survey of Canadian federal public service employees conducted in 2014.

\section{Methods}

\section{Data source and analytic sample}

The Public Service Employee Survey (PSES) is a crosssectional census survey conducted every 3 years by the Government of Canada's Office of the Chief Human Resources Officer in collaboration with Statistics Canada (Statistics Canada 2014). The survey is conducted to gather employees' opinions about their engagement, leadership, workforce, and workplace. The current study used the 2014 cycle of the PSES survey that included all federal public service employees with the exception of members of the Royal Canadian Mounted Police and non-public service employees from Foreign Affairs, Trade, and Development Canada working abroad. Out of approximately 250,000 employees, 182,165 responded to the 2014 cycle of the survey (response rate $=71.4 \%)$ (Statistics Canada 2014). Of the respondents, $3.6 \%(n=6423)$ were excluded from the analytic sample due to non- or incomplete responses to one or more of the survey questions used to construct the study variables. The final analytic sample included 175,742 respondents.

\section{Study variables}

Respondents were asked if they have been the victim of harassment or discrimination on the job in the last 2 years. Answers to these questions were used to form the outcome variables harassment (yes/no) and discrimination (yes/no). The primary explanatory variable was self-reported disability (yes/ no). Other study covariates included age (5-year age groups), 
gender (men/women), and ethnicity (Aboriginal peoples, visible minorities, other). Definitions of harassment, discrimination, disability, visible minority, and Aboriginal peoples were provided on the questionnaire (Appendix 1).

\section{Analysis plan}

Ethics approval was covered by the University of British Columbia Policy No. 89 and the Tri-Council Policy Statement: Ethical Conduct for Research Involving Humans (article 2.2) governing the use of publically available survey data (The University of British Columbia Board of Governors 2012). Analyses were conducted using SAS 9.4.(SAS Institute Inc. 2018). Sampling weights provided by Statistics Canada were applied to account for non-response.

The distribution of the study variables was examined among the entire analytic sample as well as by disability. The crude associations between disability and harassment, and disability and discrimination, were measured using bivariable logistic regression models. Confounding was investigated by adding each covariate to the bivariable logistic models one by one. Multivariable logistic regression models were then used to examine the disability-harassment and disability-discrimination relationships, adjusted for age, gender, and ethnicity. Additive and multiplicative effect modifications by age, gender, and ethnicity were examined by adding product terms to adjusted linear binomial and logistic regression models, respectively (Spiegelman and Hertzmark 2005). Effect modification is often scale dependent as absence of effect modification on the additive scale implies its presence on the multiplicative scale and vice versa. For this reason, investigation of effect modification using both additive and multiplicative scales is recommended (Rothman et al. 2007).

Recommendations by Knol and VanderWeele (2012) were followed to present the effect modification analyses. SAS estimate statements were used to calculate risk differences and odds ratios, and their $95 \%$ confidence intervals for disability within strata of the potential effect modifiers, and for disability with the presence of an effect modifier relative to the reference category (no disability, no effect modifier present). Profile likelihood confidence intervals were calculated for the risk differences from the linear binomial models, as these perform better than Wald-based confidence intervals for additive models (Maldonado and Greenland 1994). Last, the interaction contrast and the ratio of odds ratios with $95 \%$ confidence intervals and $p$ values were presented as measures of effect modification on the additive and multiplicative scales, respectively (Knol and VanderWeele and 2012).

\section{Results}

\section{Study sample}

Overall, $6.3 \%$ of respondents identified as a person with a disability. Compared with respondents with no disability, respondents with a disability were less likely to be visible minorities ( 9.7 versus $15.3 \%$ ) and under the age of 45 years ( 34.9 versus $50.4 \%$ ) but more likely to be Aboriginal peoples (9.1 versus $4.3 \%$ ) (Table 1 ).

The overall study sample was $55.7 \%$ women, and the majority $(80.4 \%)$ was not visible minorities or Aboriginal peoples. Workers aged 50 to 54 years were more common $(17.7 \%)$ compared with other age groups with a smaller number of respondents under 25 years $(2.8 \%), 25$ to 29 years $(6.4 \%)$, or over 60 years $(5.9 \%)$ (Table 1$)$.

\section{Harassment}

Within the sample as a whole, $18.4 \%$ of respondents reported harassment on the job in the last 2 years (Table 1). Descriptively, respondents with a disability were more than twice as likely to report harassment than respondents with no disability (37.0 versus $17.1 \%$ ). In bivariable logistic regression, odds of harassment were higher for workers with a disability compared with workers with no disability $(\mathrm{OR}=2.83$; 95\% CI, 2.72 to 2.97) (Table 2). Similar results were found in the multivariable logistic regression model adjusted for gender, ethnicity, and age $(\mathrm{OR}=2.80 ; 95 \% \mathrm{CI}, 2.68$ to 2.92$)$ (Table 2).

For the covariates, women had higher odds of harassment than men (OR $=1.28 ; 95 \% \mathrm{CI}, 1.25$ to 1.32$)$ (Table 2). Compared with respondents who identified as other ethnicities, visible minorities had slightly higher odds of harassment $(\mathrm{OR}=1.11 ; 95 \% \mathrm{CI}, 1.07$ to 1.15$)$ and Aboriginal peoples had almost twice the odds ( $\mathrm{OR}=1.84 ; 95 \% \mathrm{CI}, 1.74$ to 1.94$)$. Odds of harassment were lowest in the youngest age group (under age 25) and then increased with age until the age of 40 to 44 years $(\mathrm{OR}=2.07 ; 95 \% \mathrm{CI}, 1.78$ to 2.42$)$. After ages 40 to 44 years, the odds of harassment decreased with age but remained elevated compared with the youngest age group. None of the study covariates were significant confounders of the disability-harassment relationship. Individual addition of the covariates to the bivariate logistic model caused less than a $3 \%$ change to the coefficient for the relationship between disability and harassment.

On the multiplicative scale, age, gender, and ethnicity did not significantly modify the disability-harassment relationship (Table 3). On the additive scale, the difference in the risk of harassment between workers with and without a disability increased with age until age 40 to 44 years (IC $=15$ cases per 100 workers; $95 \%$ CI, 7.53 to 20.67), and then decreased 
Table 1 Descriptive characteristics for the overall study sample by disability status

\begin{tabular}{lccc}
\hline & Overall $(n=175,742)$ & $\begin{array}{l}\text { No disability } \\
(n=164,688,93.6 \%)\end{array}$ & $\begin{array}{l}\text { Disability } \\
(n=11,074,6.3 \%) \\
\text { Frequency }(\%)^{*}\end{array}$ \\
\hline $\begin{array}{l}\text { Frequency }(\%)^{*} \\
\text { Harassment }\end{array}$ & $31,321(18.4)$ & $27,366(17.1)$ & $3955(37.0)$ \\
Discrimination & $13,382(7.9)$ & $10,609(6.7)$ & $2773(25.9)$ \\
Gender & & & $4891(45.8)$ \\
Men & $75,034(44.3)$ & $70,143(44.2)$ & $6183(54.2)$ \\
Women & $100,708(55.7)$ & $94,525(55.8)$ & \\
Ethnicity & & & $9012(81.2)$ \\
Other & & $131,795(80.4)$ & $970(9.1)$ \\
Visible minorities & $140,771(80.4)$ & $26,174(15.3)$ & $119(1.4)$ \\
Aboriginal peoples & $27,266(15.0)$ & $6735(4.3)$ & $315(2.9)$ \\
Age & $7705(4.6)$ & & $782(7.1)$ \\
Under 25 & & $4166(2.8)$ & $1118(9.8)$ \\
25 to 29 & $4285(2.8)$ & $10,871(6.7)$ & $1506(13.7)$ \\
30 to 34 & $11,186(6.4)$ & $19,077(11.5)$ & $1879(16.9)$ \\
35 to 39 & $19,859(11.3)$ & $24,067(14.5)$ & $2507(22.5)$ \\
40 to 44 & $25,185(14.2)$ & $24,676(14.9)$ & $1846(16.6)$ \\
45 to 49 & $26,182(14.8)$ & $25,545(15.4)$ & $1002(9.1)$ \\
50 to 54 & $27,424(15.5)$ & $28,771(17.4)$ & $18,171(11.1)$ \\
55 to 59 & $31,278(17.7)$ & $9324(5.7)$ & \\
60 and over & $20,017(11.4)$ & & \\
\hline
\end{tabular}

*Weighted statistics

${ }^{\dagger}$ Not visible minorities or Aboriginal peoples with increasing age but remained elevated relative to the reference group (under 25 years of age) (Table 4).

\section{Discrimination}

Within the sample as a whole, $8 \%$ of respondents reported discrimination on the job in the last 2 years (Table 1). Descriptively, respondents with a disability were almost four times as likely to report discrimination than respondents with no disability (25.9 versus $6.7 \%$ ). In bivariable logistic regression, odds of discrimination were higher for workers with a disability compared with workers with no disability $(\mathrm{OR}=$ 4.86; $95 \%$ CI, 4.63 to 5.11) (Table 2). Similar results were found in the multivariable logistic regression model adjusted for gender, ethnicity, and age $(\mathrm{OR}=4.97 ; 95 \% \mathrm{CI}, 4.72$ to 5.23) (Table 2).

For the covariates, odds of discrimination were similar for women and men (Table 2). Compared with respondents who identified as other ethnicities, visible minorities $(\mathrm{OR}=2.13$; 95\% CI, 2.04 to 2.23) and Aboriginal peoples $(\mathrm{OR}=2.20$; 95\% CI, 2.04 to 2.37) had almost twice the odds of discrimination. Compared with the youngest age group who had the lowest odds of discrimination, all other age groups had increased odds of discrimination. Individual addition of the covariates to the bivariable logistic model caused less than a $3 \%$ change to the coefficient for the relationship between disability and discrimination - indicating that none of these variables were significant confounders of the disabilitydiscrimination relationship.

On the multiplicative scale, no positive effect modification was observed (Table 3). However, the disability odds ratio was smaller for visible minorities (ratio of odds ratios $=0.75$; 95\% CI, 0.65 to 0.87 ) and Aboriginal peoples (ratio of odds ratios $=0.78 ; 95 \% \mathrm{CI}, 0.66$ to 0.93 ) than for respondents who were other ethnicities. On the additive scale, the difference in the risk of discrimination between workers with and without a disability was higher among visible minorities (IC $=4.49$ cases per 100 workers; $95 \% \mathrm{CI}, 1.53$ to 7.51 ) and Aboriginal peoples (IC $=6.00 ; 95 \%$ CI, 2.85 to 9.21 ) compared with respondents who were neither (Table 4). The difference in the risk of discrimination between workers with and without a disability also increased with age until 45 to 49 years (IC $=13.32$ cases per 100 workers; $95 \%$ CI, 7.25 to 18.34), and then decreased with increasing age but remained elevated relative to the reference group (under 25 years of age).

\section{Discussion}

In this study, workers with disability in the Canadian federal public service had almost three and five times the odds of workplace harassment and discrimination, respectively, 
Table 2 Unadjusted and adjusted odds ratios (OR) with $95 \%$ confidence intervals $(\mathrm{CI})$ for workplace harassment and discrimination

\begin{tabular}{|c|c|c|c|c|}
\hline & \multicolumn{2}{|l|}{ Harassment } & \multicolumn{2}{|l|}{ Discrimination } \\
\hline & $\begin{array}{l}\text { Unadjusted } \\
\text { OR }(96 \% \mathrm{CI})\end{array}$ & $\begin{array}{l}\text { Adjusted } \\
\text { OR }(96 \% \text { CI })\end{array}$ & $\begin{array}{l}\text { Unadjusted } \\
\text { OR }(96 \% \text { CI) }\end{array}$ & $\begin{array}{l}\text { Adjusted } \\
\text { OR }(96 \% \text { CI) }\end{array}$ \\
\hline \multicolumn{5}{|l|}{ Disability } \\
\hline No & 1 & 1 & 1 & 1 \\
\hline Yes & $2.84(2.72-2.97)$ & $2.80(2.68-2.92)$ & $4.86(4.63-5.11)$ & $4.97(4.72-5.23)$ \\
\hline \multicolumn{5}{|l|}{ Gender } \\
\hline Men & 1 & 1 & 1 & 1 \\
\hline Women & $1.28(1.25-1.31)$ & $1.28(1.25-1.32)$ & $0.99(0.95-1.03)$ & $1.00(0.96-1.04)$ \\
\hline \multicolumn{5}{|l|}{ Ethnicity } \\
\hline Other $^{*}$ & 1 & 1 & 1 & 1 \\
\hline Visible minorities & $1.06(1.03-1.10)$ & $1.11(1.07-1.15)$ & $1.95(1.86-2.03)$ & $2.13(2.04-2.23)$ \\
\hline Aboriginal peoples & $1.98(1.87-2.09)$ & $1.84(1.74-1.94)$ & $2.46(2.29-2.65)$ & $2.20(2.04-2.37)$ \\
\hline \multicolumn{5}{|l|}{ Age } \\
\hline Under 25 & 1 & 1 & 1 & 1 \\
\hline 25 to 29 & $1.69(1.44-1.99)$ & $1.71(1.45-2.01)$ & $1.78(1.46-2.16)$ & $1.81(1.48-2.21)$ \\
\hline 30 to 34 & $1.83(1.57-2.14)$ & $1.84(1.57-2.15)$ & $1.85(1.53-2.23)$ & $1.86(1.54-2.26)$ \\
\hline 35 to 39 & $1.97(1.69-2.30)$ & $1.97(1.68-2.30)$ & $1.95(1.62-2.35)$ & $1.97(1.63-2.39)$ \\
\hline 40 to 44 & $2.07(1.78-2.42)$ & $2.03(1.73-2.37)$ & $1.97(1.64-2.38)$ & $1.91(1.58-2.32)$ \\
\hline 45 to 49 & $2.07(1.77-2.41)$ & $2.00(1.71-2.34)$ & $1.90(1.58-2.29)$ & $1.82(1.50-2.20)$ \\
\hline 50 to 54 & $2.01(1.72-2.35)$ & $1.94(1.66-2.26)$ & $1.94(1.61-2.33)$ & $1.88(1.55-2.27)$ \\
\hline 55 to 59 & $1.88(1.61-2.20)$ & $1.80(1.54-2.11)$ & $2.00(1.66-2.42)$ & $1.90(1.57-2.31)$ \\
\hline 60 and over & $1.66(1.42-1.95)$ & $1.59(1.36-1.88)$ & $2.09(1.72-2.54)$ & $1.90(1.56-2.33)$ \\
\hline
\end{tabular}

*Not visible minorities or Aboriginal peoples compared with workers without disability. The study also demonstrated that the relationships between disability and workplace harassment and discrimination are modifiable by other social identities including age and ethnicity. On the additive scale, the impacts of disability on workplace harassment and discrimination were amplified among workers of older age, especially among those in their 40s, and the impacts of disability on workplace discrimination were amplified among visible minorities and Aboriginal peoples. Findings from the additive models are emphasized here, as significant additive effect modification is more informative for social causation than absent or negative multiplicative effect modification (Rothman et al. 2007). In particular, the interaction contrast indicates the absolute risk associated with two social identities acting conjointly on the outcome (e.g., disability and age), in addition to the independent absolute main effects of each of these social identities.

The proportion of disabled workers who reported discrimination in the current study using 2014 survey data $(27 \%)$ is in line with previous studies conducted in the USA (Snyder et al. 2010; Balser 2002). The prevalence reported here remains high in the context of the Canadian Human Rights Act as well as organizationallevel policy implemented by the Canadian federal government to protect its employees from harassment
(Government of Canada 2013). The finding that disability is positively associated with experiences of workplace harassment and discrimination in Canada is similar to findings from Fevre et al. (2013), who found that workers with disability in the UK are at increased risk of ill treatment while at work.

There are multiple potential explanations for the finding that disability is associated with increased odds of workplace harassment and discrimination. First, Canadian workers with disability are over represented in low skill, low-pay jobs (Maroto and Pettinicchio 2014) and thus, may experience more workplace harassment and discrimination due to having low occupational power and status. While contextual factors can influence the nature of harassment at work, the direction of harassment often reflects the balance of power in an organization (Hoel and Beale 2006). For example, a 2000 survey of the British workforce found that three out of four instances of workplace bullying were by managers to workers (Hoel and Cooper 2000). Second, from 2010 to 2014 approximately 35,000 Canadian federal public service jobs were lost due to cut backs, indicating low job security during the study period. Harassment is more prevalent in workplaces with low job security and workers like those with disability are most vulnerable (Robert and Harlan 2006; Landsbergis et al. 
Table 3 Modification of the relationships between disability and workplace harassment and discrimination on the multiplicative scale

\begin{tabular}{|c|c|c|c|c|}
\hline & $\begin{array}{l}\text { No disability } \\
\text { OR }(95 \% \mathrm{CI})^{*}\end{array}$ & $\begin{array}{l}\text { Disability } \\
\text { OR }(95 \% \mathrm{CI}) *\end{array}$ & $\begin{array}{l}\text { OR }(95 \% \mathrm{CI})^{*} \\
\text { for disability } \\
\text { within strata }\end{array}$ & Ratio of ORs $(95 \% \mathrm{CI})^{*}$ \\
\hline \multicolumn{5}{|l|}{ Harassment } \\
\hline \multicolumn{5}{|l|}{ Gender } \\
\hline Men & $2.92(2.74-3.13)$ & $2.92(2.74-3.13)$ & $2.92(2.74-3.13)$ & \\
\hline Women & $3.49(3.29-3.70)$ & $3.49(3.29-3.70)$ & $2.70(2.55-2.86)$ & $0.92(0.94-1.01), p=0.070$ \\
\hline \multicolumn{5}{|l|}{ Ethnicity } \\
\hline Other $^{\dagger}$ & 1 & $2.81(2.68-2.95)$ & $2.81(2.68-2.95)$ & \\
\hline Visible minorities & $1.11(1.07-1.15)$ & $3.14(2.74-3.60)$ & $2.82(2.46-3.25)$ & $1.01(0.87-1.17), p=0.945$ \\
\hline Aboriginal peoples & $1.86(1.75-1.97)$ & $4.83(4.23-5.52)$ & $2.60(2.25-3.00)$ & $0.92(0.79-1.08), p=0.308$ \\
\hline \multicolumn{5}{|l|}{ Age } \\
\hline Under 25 & 1 & $1.94(0.89-4.20)$ & $1.94(0.89-4.20)$ & \\
\hline 25 to 29 & $1.68(1.42-1.98)$ & $4.30(3.22-5.74)$ & $2.56(1.99-3.29)$ & $1.32(0.59-2.99), p=0.500$ \\
\hline 30 to 34 & $1.80(1.53-2.11)$ & $5.24(4.22-6.51)$ & $2.92(2.49-3.41)$ & $1.51(0.68-3.32), p=0.309$ \\
\hline 35 to 39 & $1.93(1.65-2.26)$ & $5.37(4.40-6.55)$ & $2.79(2.45-3.17)$ & $1.44(0.66-3.16), p=0.364$ \\
\hline 40 to 44 & $1.97(1.68-2.31)$ & $5.98(4.94-7.25)$ & $3.04(2.70-3.42)$ & $1.57(0.72-3.44), p=0.261$ \\
\hline 45 to 49 & $1.95(1.66-2.28)$ & $5.69(4.74-6.83)$ & $2.92(2.63-3.24)$ & $1.51(0.69-3.30), p=0.303$ \\
\hline 50 to 54 & $1.89(1.61-2.21)$ & $5.46(4.58-6.52)$ & $2.89(2.64-3.17)$ & $1.49(0.68-3.26), p=0.314$ \\
\hline 55 to 59 & $1.79(1.52-2.10)$ & $4.56(3.80-5.49)$ & $2.55(2.29-2.85)$ & $1.32(0.60-2.88), p=0.489$ \\
\hline 60 and over & $1.59(1.35-1.88)$ & $3.94(3.19-4.88)$ & $2.48(2.12-2.90)$ & $1.28(0.58-2.82), p=0.540$ \\
\hline \multicolumn{5}{|l|}{ Discrimination } \\
\hline \multicolumn{5}{|l|}{ Gender } \\
\hline Men & 1 & $4.83(4.47-5.21)$ & $4.83(4.47-5.21)$ & \\
\hline Women & $0.99(0.95-1.03)$ & $5.03(4.70-5.39)$ & $5.09(4.76-5.44)$ & $1.05(0.95-1.17), p=0.306$ \\
\hline \multicolumn{5}{|l|}{ Ethnicity } \\
\hline Other $^{\dagger}$ & 1 & $5.29(5.00-5.61)$ & $5.29(5.00-5.61)$ & \\
\hline Visible minorities & $2.20(2.10-2.31)$ & $8.76(7.65-10.02)$ & $3.98(3.47-4.57)$ & $0.75(0.65-0.87), p=0.000$ \\
\hline Aboriginal peoples & $2.33(2.14-2.54)$ & $9.62(8.34-11.11)$ & $4.12(3.51-4.85)$ & $0.78(0.66-0.93), p=0.005$ \\
\hline \multicolumn{5}{|l|}{ Age } \\
\hline Under 25 & 1 & $3.68(2.01-6.76)$ & $3.68(2.01-6.76)$ & \\
\hline 25 to 29 & $1.77(1.44-2.19)$ & $8.13(5.85-11.31)$ & $4.59(3.47-6.06)$ & $1.25(0.64-2.43), p=0.519$ \\
\hline 30 to 34 & $1.82(1.48-2.23)$ & $8.85(6.84-11.45)$ & $4.87(4.07-5.83)$ & $1.32(0.7-2.49), p=0.386$ \\
\hline 35 to 39 & $1.93(1.58-2.36)$ & $9.05(7.12-11.51)$ & $4.70(4.04-5.46)$ & $1.28(0.68-2.38), p=0.446$ \\
\hline 40 to 44 & $1.83(1.50-2.24)$ & $10.00(7.93-12.61)$ & $5.45(4.75-6.26)$ & $1.48(0.79-2.76), p=0.216$ \\
\hline 45 to 49 & $1.72(1.40-2.10)$ & $10.00(8.01-12.49)$ & $5.82(5.16-6.57)$ & $1.58(0.85-2.93), p=0.147$ \\
\hline 50 to 54 & $1.80(1.47-2.20)$ & $9.59(7.72-11.90)$ & $5.33(4.79-5.93)$ & $1.45(0.78-2.68), p=0.241$ \\
\hline 55 to 59 & $1.90(1.55-2.33)$ & $8.37(6.69-10.48)$ & $4.40(3.87-5.01)$ & $1.2(0.64-2.22), p=0.573$ \\
\hline 60 and over & $1.98(1.61-1.45)$ & $7.30(5.68-9.40)$ & $3.68(3.07-4.41)$ & $1.00(0.53-1.88), p=0.997$ \\
\hline
\end{tabular}

*Adjusted for all other study covariates

${ }^{\dagger}$ Not visible minorities or Aboriginal peoples

2014; Lopez et al. 2009). Third, negotiating workplace accommodations may lead to discrimination or harassment of workers with disability by managers who view these accommodations as biased, preferential, or a nuisance (Foster 2007), and the absence of reasonable accommodation when needed due to disability is discrimination (Government of Canada 1985).
Age amplified the disability-harassment and disabilitydiscrimination relationships on the additive scale. There is little literature to draw upon to explain possible mechanisms for the age finding, indicating a novel contribution to the literature. We hypothesize that compared to older workers with a disability, young workers with a disability are more likely to have entered the workforce with a disability. Having a 
Table 4 Modification of the relationships between disability and workplace harassment and discrimination on the additive scale

\begin{tabular}{|c|c|c|c|c|}
\hline & $\begin{array}{l}\text { No disability } \\
\text { RD }(95 \% \text { CI })^{*} \dagger\end{array}$ & $\begin{array}{l}\text { Disability } \\
\mathrm{RD}(95 \% \mathrm{CI})^{*}, \dagger\end{array}$ & $\begin{array}{l}\mathrm{RD}(95 \% \mathrm{CI})^{*}, \dagger \\
\text { for disability } \\
\text { within strata }\end{array}$ & Interaction contrast $(95 \% \mathrm{CI})^{*}, \dagger$ \\
\hline \multicolumn{5}{|l|}{ Harassment } \\
\hline \multicolumn{5}{|l|}{ Gender } \\
\hline Men & 0 & $19.02(17.70-20.36)$ & $19.02(17.70-20.36)$ & \\
\hline Women & $3.60(3.24-3.96)$ & $23.25(21.99-24.51)$ & $19.65(18.39-20.90)$ & $0.62(-1.21-2.45), p=0.504$ \\
\hline \multicolumn{5}{|l|}{ Ethnicity } \\
\hline Other ${ }^{*}$ & 0 & $19.01(18.01-20.02)$ & $19.01(18.01-20.02)$ & \\
\hline Visible minorities & $1.50(1.00-2.01)$ & $21.56(18.65-24.46)$ & $20.06(17.12-22.99)$ & $1.04(-2.04-4.17), p=0.511$ \\
\hline Aboriginal peoples & $10.35(9.30-11.41)$ & $32.38(29.29-.3547)$ & $22.04(18.79-25.29)$ & $3.02(-0.38-6.42), p=0.082$ \\
\hline \multicolumn{5}{|l|}{ Age } \\
\hline Under 25 & 0 & $7.70(2.16-14.27)$ & $7.70(2.16-14.27)$ & \\
\hline 25 to 29 & $5.56(4.46-6.64)$ & $22.16(16.94-27.38)$ & $16.60(11.40-21.80)$ & $8.9(0.65-16.67), p=0.029$ \\
\hline 30 to 34 & $6.56(5.54-7.54)$ & $26.83(23.33-30.33)$ & $20.27(16.84-23.71)$ & $12.58(5.21-19.18), p=0.000$ \\
\hline 35 to 39 & $7.58(6.59-8.54)$ & $27.53(24.54-30.53)$ & $19.95(17.04-22.86)$ & $12.25(5.10-18.57), p=0.000$ \\
\hline 40 to 44 & $7.92(6.93-8.88)$ & $30.16(17.55-32.76)$ & $22.23(19.73-24.74)$ & $14.54(7.53-20.67), p<0.000$ \\
\hline 45 to 49 & $7.81(6.92-8.76)$ & $28.83(26.47-31.19)$ & $21.02(18.77-23.27)$ & $13.33(6.40-19.34), p<0.000$ \\
\hline 50 to 54 & $7.42(6.45-8.36)$ & $27.77(25.70-29.85)$ & $20.35(18.41-22.30)$ & $12.66(5.82-18.56), p=0.000$ \\
\hline 55 to 59 & $6.54(5.52-7.53)$ & $23.52(21.20-25.84)$ & $16.98(14.76-19.21)$ & $9.29(2.37-15.30), p=0.005$ \\
\hline 60 and over & $4.99(3.87-6.08)$ & $20.52(17.58-23.46)$ & $15.54(12.63-18.44)$ & $7.84(0.69-14.16), p=0.023$ \\
\hline \multicolumn{5}{|l|}{ Discrimination } \\
\hline \multicolumn{5}{|l|}{ Gender } \\
\hline Men & 0 & $18.50(17.30-19.71)$ & $18.50(17.30-19.71)$ & \\
\hline Women & $0.02(-0.21-0.25)$ & $19.53(18.40-20.65)$ & $19.51(18.38-20.63)$ & $1.01(-0.64-2.65), p=0.229$ \\
\hline \multicolumn{5}{|l|}{ Ethnicity } \\
\hline Other & 0 & $18.19(17.31-19.09)$ & $18.19(17.31-19.09)$ & \\
\hline Visible minorities & $5.77(5.36-6.81)$ & $28.45(25.62-31.28)$ & $22.68(19.83-25.53)$ & $4.49(1.53-7.51), p=0.003$ \\
\hline Aboriginal peoples & $6.45(5.69-7.23)$ & $30.64(27.68-33.60)$ & $24.20(21.14-27.25)$ & $6.00(2.85-9.21), p=0.000$ \\
\hline \multicolumn{5}{|l|}{ Age } \\
\hline Under 25 & 0 & $8.30(3.79-14.05)$ & $8.30(3.79-14.05)$ & \\
\hline 25 to 29 & $2.32(1.61-3.01)$ & $18.90(14.18-23.61)$ & $16.58(11.87-21.28)$ & $8.28(1.03-15.05), p=0.020$ \\
\hline 30 to 34 & $2.32(1.67-2.94)$ & $21.30(18.18-24.42)$ & $18.98(15.89-22.07)$ & $10.68(4.23-16.27), p=0.001$ \\
\hline 35 to 39 & $2.63(2.00-3.23)$ & $21.62(18.96-24.28)$ & $18.99(16.36-21.61)$ & $10.69(4.42-16.00), p=0.000$ \\
\hline 40 to 44 & $2.21(1.58-2.80)$ & $23.68(21.37-26.00)$ & $21.47(19.20-23.75)$ & $13.17(7.03-18.30), p=0.000$ \\
\hline 45 to 49 & $1.75(1.13-2.34)$ & $23.37(21.27-25.47)$ & $21.62(19.57-23.67)$ & $13.32(7.25-18.34), p=0.000$ \\
\hline 50 to 54 & $2.08(1.46-2.66)$ & $21.86(20.06-23.67)$ & $19.79(18.04-21.53)$ & $11.49(5.51-16.37), p=0.000$ \\
\hline 55 to 59 & $2.49(1.83-3.11)$ & $19.58(17.56-21.60)$ & 17.09 (15.11-19.07) & $8.79(2.74-13.78), p=0.002$ \\
\hline 60 and over & $2.63(0.37-1.89)$ & $17.55(14.97-20.14)$ & $14.92(12.34-17.50)$ & $6.62(0.38-11.92), p=0.024$ \\
\hline
\end{tabular}

*Per 100 employees

${ }^{\dagger}$ Adjusted for all other study covariates

*Not visible minorities or Aboriginal peoples

disability at the time of workforce entry may influence job placement. Thus young workers with a disability may be more likely to have a job where they experience less disability related impairment or where accomodation is more easily negotiated.Older workers, on the other hand, may be more likely to have new onset disability associated with chronic diseases, and may experience challenges navigating accommodation in a current or long-term job that translates to increased harassment and discrimination. Further, older workers who become disabled during their working career, may be more likely to perceive or experience discrimination and harassment as a result of this transition (i.e., feel that they are being treated differently) than workers who have had a disability their entire working career. 
Ethnicity amplified the disability-discrimination relationship on the additive scale. This may be due to higher socioeconomic levels among Canadians who are not a visible minority or Aboriginal peoples. In Canada, the median incomes for workers who identify as a visible minority or as Aboriginal peoples are respectively $11 \%$ and $24 \%$ lower than the median income for the total working population (Statistics Canada 2011). People from higher socioeconomic backgrounds may use their social and material wealth to counter the occupational disadvantages associated with disability. For example, purchase of non-insured health services and assistive devices can increase work functioning that may lower work productivity stigma. Conversely, disability-related stigma among ethnic minorities (Scior et al. 2013) might result in greater disempowerment of people with disabilities within these groups that in turn could increase workplace harassment and discrimination vulnerability. Similar non-significant effect modification was observed in the linear binomial harassment model.

Compared with men, women experienced higher odds of workplace harassment but not discrimination, regardless of disability status. Additionally, gender did not modify the main relationships of interest. In a recent study by Shaw et al., women experienced more workplace harassment than men in a sample of working Americans with disability (Shaw et al. 2012). This is in accordance with our finding that significantly more cases of workplace harassment were observed among women with disability than among men with disability. While the main effects of gender and disability have been described before, the role of gender as an effect modifier of the disability-workplace harassment and the disabilityworkplace discrimination relationships remains relatively unexamined, indicating a novel contribution of this study.

Major strengths of this study include the use of a large sample representative of the Canadian federal public service and examination of the intersection of disability with age, gender, and ethnicity. However, this study has several limitations. First, the findings may be unique to Canadian public service employees. The impact of a given social identity on the risk of workplace harassment and discrimination depends not only on its intersection with other social identities but also contextual factors such as processes of oppression or privilege and workplace policies and institutional practices (Bauer 2014). Contextual factors may vary notably across industry types, geographic regions, employers, and countries. In the context of long-standing Canadian labour laws and Human Rights Act, the observed associations in the current study may be stronger in other countries without such protections or contextual influences. Second, there may be notable heterogeneity within the categories of social identity. Due to the use of existing survey data, we were not able to distinguish between different disability types or the specific ethnicities of workers who were visible minorities or Aboriginal peoples. Our finding that disability and ethnicity are important determinants of workplace harassment and discrimination in Canada indicates that future research should examine these two social identities in greater detail.

Current findings highlight the need to consider the intersection of disability with age, gender, and ethnicity in intervention planning. With regard to age, the transition from a non-disability to a disability state with the onset of chronic conditions in middle age may represent a common time-point in the life course where workplace harassment and discrimination vulnerability is heightened, and thus a suitable target for intervention efforts in an aging workforce. With regard to ethnicity, possible ethnic disparities in disability-related stigma and equitable access to work accommodation and other disabilityrelated social benefits should be considered. However, if the modification effects of ethnicity on disability are attributable to socioeconomic differences, this would necessitate more upstream interventions to promote socioeconomic equality. Finally, intervention efforts should take into consideration, independent of disability status, that women are at increased risk of workplace harassment compared with men.

In conclusion, our findings indicate that despite national legislation and employer policy, experiences of workplace harassment and discrimination are highly prevalent in the Canadian federal workforce, especially among employees with disability. While legal protection from workplace harassment and discrimination is necessary, it is not sufficient to ensure workers' rights. This echoes literature stating that existing anti-discrimination legislation in Canada is limited by reliance on complaints, investigation of individual cases, litigation, and court or tribunal orders (Prince 2010). In contrast, positive action legislation includes tools such as public awareness, standards development, timelines for implementation and compliance, and enforcement (Prince 2010). Further support and enforcement systems and employer incentives with careful consideration given to intersecting identities beyond what is currently in place are needed to reduce harassment and discrimination in the workforce as a whole, as well as to create an inclusive supportive environment for workers with disability, and other marginalized groups.

\section{Compliance with ethical standards}

Disclaimer Although the research and analysis are based on data from Statistics Canada, the opinions expressed do not represent the views of Statistics Canada.

Sources of support Jones and Finkelstein are supported in part by the Centre for Research on Work Disability Policy. Jones and Koehoorn are supported in part by the Partnership for Work Health and Safety, a research partnership between WorkSafeBC (provincial workers' compensation system) and the University of British Columbia. Jones is supported 
in part by the CIHR Bridge Strategic Training Program and WorkSafeBC. This research was supported by funds to the Canadian Research Data Centre Network (CRDCN) from the Social Sciences and Humanities Research Council (SSHRC), the Canadian Institutes of Health Research (CIHR), the Canadian Foundation for Innovation (CFI), and Statistics Canada.

Conflict of interest The authors declare that they have no conflict of interest.

\section{Appendix 1}

Key definitions provided to respondents on the 2014 PSES questionnaire:

Harassment is normally a series of incidents, but it can be one severe incident that has a lasting impact on the individual. Harassment is any improper conduct by an individual that is directed at and offensive to another individual in the workplace, including at any event or any location related to work, and that the individual knew or ought reasonably to have known would cause offense or harm. It comprises objectionable act(s), comment(s), or display(s) that demean, belittle, or cause personal humiliation or embarrassment, and any act of intimidation or threat. It also includes harassment within the meaning of the Canadian Human Rights Act (i.e., based on race, national or ethnic origin, color, religion, age, sex, sexual orientation, marital status, family status, disability, and pardoned conviction or suspended record).

Discrimination means treating someone differently or unfairly because of a personal characteristic or distinction, which, whether intentional or not, has an effect that imposes disadvantages not imposed on others, or that withholds or limits access that is given to others. There are 11 prohibited grounds of discrimination under the Canadian Human Rights Act: race, national or ethnic origin, color, religion, age, sex, sexual orientation, marital status, family status, disability, and pardoned conviction or suspended record.

A person with a disability has a long-term or recurring physical, mental, sensory, psychiatric or learning impairment and considers himself or herself to be disadvantaged in employment by reason of that impairment, or believes that an employer or potential employer is likely to consider him or her to be disadvantaged in employment by reason of that impairment. Persons with disabilities are also those whose functional limitations owing to their impairment have been accommodated in their current job or workplace.

A member of a visible minority in Canada may be defined as someone (other than an Aboriginal person) who is non-white in color or race, regardless of place of birth. For example: Black, Chinese, Filipino, Japanese, Korean, South Asian or East Indian, Southeast Asian, non-white
West Asian, North African or Arab, non-white Latin American, person of mixed origin (with one parent in one of the visible minority groups in this list), or other visible minority group.)

An Aboriginal person is a North American Indian or a member of a First Nation, a Métis or an Inuk (Inuit). North American Indians or members of a First Nation include status, treaty or registered Indians, as well as non-status and non-registered Indians.

\section{References}

Australian Government (2009) Fair Work Act 2009. Act No. 28 of 2009. Available at: https://www.legislation.gov.au/Details/C2017C00144. Accessed 8 August 2017).

Balser, D. B. (2002). Agency in organizational inequality: organizational behavior and individual perceptions of discrimination. Work Organ, 29(2), 137-165.

Bauer, G. R. (2014). Incorporating intersectionality theory into population health research methodology: Challenges and the potential to advance health equity. Soc Sci Med, 110, 10-17. https://doi.org/10. 1016/j.socscimed.2014.03.022.

Fevre, R., Robinson, A., Lewis, D., \& Jones, T. (2013). The ill-treatment of employees with disabilities in British workplaces. Work Employ Soc, 27(2), 288-307. https://doi.org/10.1177/0950017012460311.

Foster, D. (2007). Legal obligation or personal lottery? Employee experiences of disability and the negotiation of adjustments in the public sector workplace. Work Employ Soc, 21(1), 67-84. https://doi.org/ 10.1177/0950017007073616.

Gee, G. C., Pavalko, E. K., \& Long, J. S. (2007). Age, cohort and perceived age discrimination: using the life course to assess selfreported age discrimination. Soc Forces, 86(1), 265-290.

Government of Canada (1985) The Canadian Human Rights Act of 1985. Available at: http://laws-lois.justice.gc.ca/eng/acts/H-6/. Accessed 8 August 2017.

Government of Canada. Policy on harassment prevention and resolution. 2013. Available at: http://www.tbs-sct.gc.ca/pol/doc-eng.aspx?id= 26041. Accessed 26 June 2017.

Hoel, H., \& Beale, D. (2006). Workplace bullying, psychological perspectives and industrial relations: towards a contextualized and interdisciplinary approach. Br J Ind Relat, 44(2), 239-262. https://doi. org/10.1111/j.1467-8543.2006.00496.x.

Hoel H, Cooper C. (2000) Destructive conflict and bullying at work. Unpublished report. Manchester School of Management, University of Manchester Institute of Science and Technology Available at: http://www.bollettinoadapt.it/old/files/document/ 19764Destructiveconfl.pdf. Accessed 4 November 2017.

Ineson, E. M., Yap, M. H. T., \& Whiting, G. (2013). Sexual discrimination and harassment in the hospitality industry. Int $J$ Hosp Manag, 35, 1-9. https://doi.org/10.1016/j.ijhm.2013.04.012.

Khubchandani, J., \& Price, J. H. (2015). Workplace harassment and morbidity among US adults: results from the national health interview survey. J Community Health, 40(3), 555-563. https://doi.org/10. 1007/s10900-014-9971-2.

Knol, M. J., \& VanderWeele, T. J. (2012). Recommendations for presenting analyses of effect modification and interaction. Int J Epidemiol, 41(2), 514-520. https://doi.org/10.1093/ije/dyr218.

Landsbergis, P. A., Grzywacz, J. G., \& LaMontagne, A. D. (2014). Work organization, job insecurity, and occupational health disparities. $A m$ 
Journal Ind Med, 57(5), 495-515. https://doi.org/10.1002/ajim. 22126.

Lopez, S. H., Hodson, R., Roscigno, V. J., Lopez, S. H., Hodson, R., \& Roscigno, V. J. (2009). Power, status, and abuse at work: General and sexual harassment compared. Sociol Q, 50(1), 3-27.

Maldonado, G., \& Greenland, S. (1994). A comparison of the performance of model-based confidence intervals when the correct model form is unknown: coverage of asymptotic means. Epidemiology, 5(2), 171-182. https://doi.org/10.1097/00001648-19940300000007.

Maroto, M., \& Pettinicchio, D. (2014). Disability, structural inequality, and work: the influence of occupational segregation on earnings for people with different disabilities. Res Soc Stratif Mobil, 38, 76-92. https://doi.org/10.1016/j.rssm.2014.08.002.

Okechukwu, C. A., Souza, K., Davis, K. D., \& de Castro, A. B. (2014). Discrimination, harassment, abuse and bullying in the workplace: contribution of workplace injustice to occupational health disparities. Am J Ind Med, 586(57), 573-586. https://doi.org/10.1002/ ajim.22221.

Pascoe, E. A., \& Smart Richman, L. (2009). Perceived discrimination and health: a meta-analytic review. Psychol Bull, 135(4), 531-554. https://doi.org/10.1037/a0016059.

Prince, M. J. (2010). What about a disability rights act for Canada? Practices and lessons from America, Australia, and the United Kingdom. Canadian Public Policy, 36(2), 199-214.

Robert, P. M., \& Harlan, S. L. (2006). Mechanisms of disability discrimination in large bureaucratic organizations: ascriptive inequalities in the workplace. Sociol Q, 47(4), 599-630. https://doi.org/10.1111/j. 1533-8525.2006.00060.x.

Rospenda, K. M., Richman, J. A., \& Shannon, C. A. (2009). Prevalence and mental health correlates of harassment and discrimination in the workplace: results from a national study. J Interpers Violence, 24(5), 819-843. https://doi.org/10.1177/0886260508317182.

Rothman, K. J., Greenland, S., \& Lash, T. L. (2007). Modern epidemiology (3rd ed.). Philadelphia, PA: Lippincott Williams \& Wilkins.

SAS Institute Inc. (2018) SAS 9.4 Software | SAS. http://www.sas.com/ en_us/software/sas9.html. Accessed 9 December 2014.
Scior, K., Addai-Davis, J., Kenyon, M., \& Sheridan, J. C. (2013). Stigma, public awareness about intellectual disability and attitudes to inclusion among different ethnic groups. J Intellect Disabil Res, 57(11), 1014-1026. https://doi.org/10.1111/j.1365-2788.2012.01597.x.

Shaw, L. R., Chan, F., \& McMahon, B. T. (2012). Intersectionality and disability harassment: the interactive effects of disability, race, age, and gender. Rehabil Couns Bull, 55(2), 82-91. https://doi.org/10. 1177/0034355211431167.

Snyder, L. A., Carmichael, J. S., Blackwell, L. V., Cleveland, J. N., \& Thornton, G. C. (2010). Perceptions of discrimination and justice among employees with disabilities. Empl Responsib Rights J, 22(1), 5-19. https://doi.org/10.1007/s10672-009-9107-5.

Spiegelman, D., \& Hertzmark, E. (2005). Easy SAS calculations for risk or prevalence ratios and differences. Am J Epidemiol, 162(3), 199 200. https://doi.org/10.1093/aje/kwi188.

Statistics Canada. 2011 National household survey. Catalogue number 99-014-X2011041. Available at: http://www12.statcan.gc.ca/nhsenm/2011/dp-pd/dt-td/Rp-eng.cfm?TABID=4\&LANG=E\&A= $\mathrm{R} \& \mathrm{APATH}=7 \& \mathrm{DETAIL}=0 \& \mathrm{DIM}=0 \& \mathrm{FL}=\mathrm{I} \& \mathrm{FREE}=0 \& \mathrm{GC}=$ $00 \& \mathrm{GL}=-1 \& \mathrm{GID}=1142052 \& \mathrm{GK}=1 \& \mathrm{GRP}=0 \& \mathrm{O}=\mathrm{D} \& \mathrm{PID}=$ $106746 \& \mathrm{PRID}=0 \& \mathrm{PTYPE}=105277 \& \mathrm{~S}=0 \& \mathrm{SHOWALL}=$ $0 \&$ SUB $=0 \&$ Temporal $=2013 \&$ THEME $=98 \&$ VID $=0 \&$ VNAMEE $=$ Income and e. Accessed 2 July 2017.

Statistics Canada. (2014) Microdata user guide: public service employee survey 2014. Ottawa, ON.

The Council of the European Union (2009) Council Directive 2000/78/ EC of 27 November 2000 establishing a general framework for equal treatment in employment and occupation. Off Journal L 303;16-22. Available at: http://eur-lex.europa.eu/LexUriServ/ LexUriServ.do?uri=CELEX:32000L0078:en:HTML. Accessed 8 August 2017.

The University of British Columbia Board of Governors (2012). Research involving human participants. 2012. Available at: http:// universitycounsel.ubc.ca/files/2012/06/policy89.pdf. Accessed 8 December 2014.

U.S. Equal Employment Opportunity Commission (1990) Americans with Disabilities Act. Public Law 101-336. 42 U.S.C. 12111, 12112. Available at: https://www.ada.gov/pubs/adastatute08.pdf. Accessed 8 August 2017. 